Studia Anglica Posnaniensia 47, 2-3, 2012

doi: 10.2478/v10121-012-0008-6

\title{
MARGARET FULLER'S CONVERSATIONS: SPEAKING AS REVISION AND FEMINIST RESISTANCE
}

\author{
RULA QUAWAS
}

University of Jordan, Amman

\begin{abstract}
Conversation as a means to social, intellectual, and spiritual self-culture was advocated during the American Romantic period by members of the Transcendental movement. Margaret Fuller was a transcendental conversationalist who challenged the theoretical setting and practice of selfculture, remedied the gap in it about concepts of womanhood that were imposed by the culture of the time and that attempted to determine women's place in the symbolic order, and placed an emphasis on self-knowledge, whatever the subject matter. She came to represent a rhetoric whose aim was to foster community, moral truths, ethical actions, and feminist resistance. Fuller fully subscribed to the idea of the revelatory power in conversation and provided women with an opportunity to develop the intellectual rigor necessary to establish their own identities in the world: public or private. Through her weekly conversations for Boston women, held from 1839 through 1844 , she used conversation or speaking as revision to explore philosophical, aesthetic, and sociocultural questions and supplied access to education from which women were excluded.
\end{abstract}

Women who speak in public, if they have a moral power ... that is if they speak for conscience' sake, to serve a cause which they hold sacred ... subdue the prejudices of their hearers (Margaret Fuller, Woman in the nineteenth century, 110).

A newborn baby begins his metamorphosis from hungry neonate to human child as he hears voices speaking. First, he responds with actions: his eyes look to the sound, his face turns to the speaking face, his hands gesture toward the speaker. Later, he coos and gurgles and exclaims; he acquires language. In all cultures and with all peoples, the child's humanity begins with the spoken word - spoken in conversation. Conversation, the dialogic exchange of information between individuals, is the first way we learn language and begin to understand ourselves and the world. Later, the spoken word provides the primary way by 
which we create, furthering or hindering, our personal and professional relationships. And if we are lucky, conversation also provides us with continuing intellectual and spiritual inspiration for this earthly life.

Conversation as a means to social, intellectual, and spiritual self-culture was advocated during the American Romantic period by members of the Transcendental Movement. From his early days as a peddler of wares in the South to his later years as a peddler of truths in the West, Amos Bronson Alcott thought of himself as a wandering talker. He also used dialogue in his classrooms as a technique to elicit truths from the mouths and minds of children. As he wrote his mother in 1839: "But I am living rather by Talking now, than by school: and shall be able, by and by, I think to live in this way entirely" (Alcott 1969: 41).

Alcott was not the only transcendentalist to live by Talking. Three years before she met Emerson or worked for Alcott, Margaret Fuller - more formally, Sarah Margaret Fuller, the Marchesa Ossoli - was talking and writing about the value of talking. In a letter to Frederick H. Hedge, she said: "Nobody can be more sensible than myself that the pen is a much less agreeable instrument for communication than the voice, but all our wishes will not bring back the dear talking times of Greece and Rome" (Fuller 1983, 1: 189). After serving as a recorder for some of Alcott's dialogues with children at the Temple School, Fuller tried to resurrect those "dear talking times of Greece and Rome" in weekly conversations for Boston women, held from 1839 through 1844.

While Alcott and Fuller were talking, Ralph Waldo Emerson analyzed the nature and power of conversation in his essays, lectures, and journals. Although Emerson's journals showed his ambivalence about participation in group conversations, his essays and lectures promoted the values of spontaneous, one-onone dialogue, or liberal conversation, between friends. Emerson ranked conversation equal with literature and religion as a means to "afford us a platform from whence we may command a view of our present life" (Emerson 19031904, 2: 185). Discourse between individuals in Emerson's poetics of conversation was both divinely inspired and evanescent:

\footnotetext{
Conversation is a game of Circles ... We all stand waiting, empty - knowing, possibly, that we can be full, surrounded by mighty symbols which are not symbols to us, but prose and trivial toys. Then cometh the god, and converts the statues into fiery men, and by a flash of his eyes burns up the veil which shrouded all things (Emerson 1903-1904, 2: 184).
}

Alcott, Fuller, and Emerson came to advocate inspired conversation as a practical means to self-culture, philosophical revelation, and intellectual and spiritual ends. Like her fellow transcendentalists, Fuller admired oral intellectual discourse because it promoted originality and intellectual self-reliance. However, more than Emerson or Alcott, or indeed far more than any other leading Tran- 
scendentalist, Fuller was associated with both the literary-intellectual and the social reform of Transcendentalism. It was Fuller's position as a woman in a culture dominated by men that led her to claim for women the same right to self-culture that Emerson and other transcendentalists claimed for themselves as a male privilege. At once making an individualistic and radical, yet productive, move, Fuller revised and rewrote the popular transcendentalist theory of selfculture, a "version of human perfectibility centered around a metaphor of the soul as a dynamic organism capable of cultivation to ever-increasing harmonious growth" (Robinson 1982: 84). Fuller transformed the politics of self-culture (or self-creation, self-determination, self-cultivation, or self-knowledge, as it was often called) from one that appoints the individual a majority of one into a politics that makes the individual an activist who works to generate a new majority alliance and a community of partnership between the sexes. For the New England Transcendentalists, the public realm became the place for self-culture, for the development and growth of an individual vision that would agitate the consciousness and the conscience that would ensure in the enlightened self correct thought and action. For them, social reform began with this reform of the individual. And while for Emerson and Thoreau it seemed to end with the individual as well, for others, like Margaret Fuller, it came to require community building and active participation in political public discourse.

In essence, Fuller believed in the power of the individual, as other transcendentalists did, but she came to represent a rhetoric whose aim was to foster community, moral truths, and ethical actions. For her, intellectual self-culture accompanied and effected social change and reform, especially for women who could readily exercise power and authority to disrupt phallocentric discursive practices as well as designated gender roles and to move beyond the notion that they were too delicate or not intellectually capable of civic involvement and cultural activity. In Woman of the nineteenth century, Fuller argued, "Too much is said of women being better educated, that they may become better companions and mothers for men.... [A] being of infinite scope must not be treated with an exclusive view to any one relation" (Fuller 1971: 95-96). In her Boston Conversations, Fuller sharply challenged the theoretical setting and practice of selfculture, remedied the gap in it about concepts of womanhood that were imposed by the culture of the time and that attempted to determine women's place in the symbolic order, and placed an emphasis on self-knowledge, whatever the subject matter.

Fuller fully subscribed to the idea of the revelatory power in conversation; she realized the huge potential for intellectual self-culture in the process of dialogue and believed that intellectual self-culture could be accompanied by social, personal, or literary achievements. Her rhetorical Conversations and her evolving revision of the transcendental notion and practice of self-culture provided 
individuals, especially women, with an opportunity to develop the intellectual rigor necessary to establish their own voices in the world. Self-culture, or the life of free self-development Fuller wanted for all women, paved the way for women to make calculated and conscious choices rather than accept their preordained destiny and to voice their opinions instead of being led by the opinions of others. Fuller made self-culture a political practice and argued in "The Great Lawsuit" that relationships between men and women should be changed to enable women not "to learn their rule from without" but, like men, "to unfold it from within" (Fuller 1843: 16-17). As she explained in her introductory lecture, she was "not here to teach" but "to provoke the thought of others" in order, she said, to encourage the kind of intellectual reproduction and self-activity inside a classroom men were able to experience outside of one (Emerson 1884, 1: 329). Fuller, herself a self-actualizing and achieving woman, had the highest faith in the potential of women, and she also had the deepest trust in the likelihood of its realization.

Intriguingly, Fuller's revisionist study of the notion and practice of selfculture can be appropriately called Transcendental Feminism, a feminism whose overt expression encouraged women to shed their social trappings and excess baggage, to discover a basic core and stable concept of self, to achieve intellectual self-reliance, and to become full-fledged agents in the world. Bowing to the authority of her feminist arguments, Fuller came to reinscribe her feminism into literary texts like Summer on the Lakes, in 1843 and Woman in the nineteenth century. At the same time, Fuller evoked a standard of public morality, addressing the needs of oppressed or subaltern people and claiming the individualist notion of self-culture as a right for marginalized citizens (poor women or people of color), which ultimately led her to a call for complete social change. Fuller was certainly a privileged woman, but as her social awareness grew, Bell Gale Chevigny has observed, she learned "that other institutions had to be transformed before the oppressed could really learn, and that the privileged, for all their education, were necessarily oppressors" (Chevigny 1976: 293-294).

There are numerous studies of Margaret Fuller that describe her pedagogy; her skills as a conversationalist, editor, or journalist; her friendship with the New England circle of transcendentalists; or her feminism. ${ }^{1}$ Twentieth-century scholars have rightly called for greater attention to Fuller's literary works; however, they have often done so without emphasizing her importance as a speaker, thus averting attention from a central means by which she influenced her culture. In antebellum America's "golden age of oratory," an eloquent voice ri-

1 Interesting recent work on Fuller include Simmons (1994), Capper (1992), Watson (1988), Blanchard (1987), Cole (1998) and Fleischmann (2000). 
valed literary production for cultural esteem. Among women writers, none is so often remembered for her eloquence as Fuller, whose enduring reputation as a speaker is preserved through works of her contemporaries and successors.

Fuller's public voices - as critic, reformer, and social prophet - transformed expectations for women's speaking, opened public avenues of expression, and enabled other women to defy social conventions and to assume these new, powerful roles for themselves. In debating vocal versus written expressions, Fuller admonished herself to enjoy the "miraculous benefits of silence," and concluded that "the expression of thought and feeling is to the mind what respiration is to the lungs and much suffering and probably injury will ensue from living in a ... harsh atmosphere" (Emerson 1884, 1: 297). Julie Ellison has astutely observed how from a very early age Fuller "regard[ed] the self as the locus of conversation among the many languages of the mind" (Ellison 1990: 223). Confronting intense opposition to women as public speakers and defying cultural expectations and perceptions of "exhibitionism," Fuller forged her own standards and policies and adopted a creative compromise: "Conversations". Semi-formal Conversations, rather than open public lectures, were acceptable because they seemed less assertive and were restricted to friends or acquaintances. They are productively liminal, occupying grey areas between the public and the private, the alternative and the mainstream, between one sub-culture and another main one.

Fuller's Conversations for Boston women beginning in 1839, like the letter that initiated them, ${ }^{2}$ represented semipublic discourse to a "select" audience (not open to strangers; held in private homes). Her eloquent conversation was considered an appropriate form of women's (private) expression - as long as it did not become dominating, critical or satirical. Assuming the authoritative position of lecturer and educator to adults, Fuller, however, was trespassing on male intellectual and professional domains. As a trespasser and a subverter of the rationale of the hegemonic masculine discourse, she was described in the same terms as the pioneering women abolitionists whose public appearances first provoked the American controversy over women's right to speak in public. In the eyes of their contemporaries, antebellum women risked their "womanhood" by becoming public speakers. Nineteenth-century sexual-biological theories taught that women would be rendered sterile through strenuous intellectual efforts such as oratory, "unsexing" themselves literally as well as figuratively. Arguing for women's silence in public, an influential annual pastoral letter (1837) by congregational ministers represented women as vines "whose

2 Fuller outlined the series of talks she proposed in a letter (the only permissible form of advertising) addressed only to her friend Sophia Ripley in August 1839. However, the letter was intended to be (and was) read by others who were interested in reading. 
strength and beauty is to lean upon the trellis-work, and half conceal its clusters" (Yoakum 1943: 163). Women who attempted public speaking would "not only cease to bear fruit, but fall in shame and dishonor in the dust" (Yoakum 1943: 163). Conventional thinking held that intellectual exertion so drained women of physical resources that it produced sterility, disease, or "nervous disorders". Speakers were said to lose their femininity, their sexual identity, by speaking in public. Horace Mann, for example, asserted: "“when a woman ... appears on the forum and makes a speech she unsexes herself" "(O'Connor 1954: 31). In attempting to participate in public discourse, women were thought to be masculinized as they entered the traditional space of males, with its strife and exposure to the coarseness, even danger of the public realm. Thus as Fuller saw, a central problem in the reception of women as public speakers was the inability of men (and many women) to see women as having both feminine sexuality and "masculine" intellect.

At the precise moment when women's speaking in public was most controversial, Fuller articulated her goals for encouraging women to speak for themselves as one of the central aims of her Conversations: "I am so sure that the success of the whole depends on conversation being general that I do not wish any one to join who does not intend, if possible, to take an active part. ... Those who do not talk will not derive the same advantages with those who openly state their impressions and consent to learn by blundering as is the destiny of Man here below" (Fuller 1983, 2: 88). She inaugurated her Conversations, mingling lecturing and discussions, spontaneity with preparation, informality with erudition, hoping to repeat her prior teaching success in which her students gradually "acquired greater command both of thoughts and language" (Fuller 1983, 2: 88) and to provide a platform for women to describe their experiences, feelings, and ideas. In her rhetorical conversations, Fuller created a polyvocal, dialogic, multi-perspectival experience for herself as well as for her audience. She created a women-centered epistemological community that would produce feminist knowledge through a process of sharing experiences and feelings and considering actions and ideas. In a recent study of comments made by her listeners, Charles Capper states that "virtually every one of [those] reports includes enthusiastic praise of Fuller's wonderful speech and conversational powers. ... Undoubtedly ... her lack of opportunity as a woman to lecture, along with her famous talent for informal talk, were also factors in attracting her to the medium [of conversation]" (Capper 1987: 516).

Because both formal higher education and professional lecturing were denied to women, Fuller's Conversations, which can be regarded as a "Vindication of woman's right to think and speak," were important in two profound ways. They provided an opportunity for women to hear a woman scholarspeaker and for the speaker to gain the satisfaction of public speaking. Gener- 
ally, women speakers who addressed other women were rewarded by finding psychological support and overcoming a sense of intellectual isolation. Fuller, for example, described the rewards of a supportive audience by writing that one conversation was "a noble meeting" in which she tried to convey the truth", adding: "though I did not arrive at any full expression of it, they all, with glistening eyes, seemed melted into one love" (Fuller 1983, 2: 183). Fuller endeavored to establish a "dialogue of love" based on understanding accompanied by constructive criticism (Fuller 1983, 2: 183). Her appreciative friends and listeners contrasted sharply with hostile male or mixed-sex audiences which confronted the pioneer women public orators.

Fuller's Conversations, like contemporary lectures, not only engaged the audience in a process marked by intellectual and emotional reciprocity, but they also supplied access to education from which women were excluded. Her Conversations can be regarded as a site of feminist resistance, a place from which to critique the forces moving women to silence and repression and a tremendous tool for fighting intellectual isolation and for establishing new lines of dialogue and inquiry. From the most thorough record available, the notes taken in 1841 by a young woman named Caroline Healey Dall, we can conclude that one value of listening to Fuller was that it educated one's power of expression (Dall 1867: 120). Similarly, Louisa May Alcott, too young to attend Fuller's Conversations, later wrote that she was "getting all I can from lectures, books, and good people. Life is my college. May I graduate well, and earn some honors!" (Cheney 1980: 275-276). Alcott recorded her responses to many lecturers, including women such as Fanny Kemble, Mrs. Richardson, Anna-Dickinson and Fuller's successor, Mary Livermore, with whom Alcott sat up talking through the night on women's rights following a Concord lecture. Women in Fuller's seminars also saw her as representing the potential power of women to engage in public intellectual vocations. The responses of women to Margaret Fuller reveal how Fuller was a representative of "the feelings of ... American women of her class: their restlessness, ambitions, and frustrations" (Chevigny 1976: 3).

Fuller understood the connection between recognition for women's intellectual abilities and opportunities for public speaking, between the silence of submissiveness and the voice of self-representation, and she found creative ways of positioning women's discourse in male / public domains. She tapped into the power of the spoken word for her Conversations and philosophical writings. Her Conversations were not alloquim, or talking to the company, but colloquim, or talking with the company. ${ }^{3}$ Elizabeth Oakes Smith (1806-1893), the first

The words "colloquim" and "alloquim" are borrowed from Thomas DeQuincey's essay "Conversation", which provides a means of tracing the complexities of post-Renaissance interest in private discourse as it continued to develop in England. In October 1847, the essay 
woman to lecture regularly for lyceums, benefited from Fuller's example as a speaker on women's issues and made Fuller a subject of her public discourse. Smith began lecturing in the year following Fuller's death (1851) and lectured on Fuller in 1854. A poet and novelist, Smith wrote a memorial poem and delivered a lecture (no longer extant) on Fuller. In her memorial poem, Smith praised Fuller's "glorious thought," her eloquence, and her heart "with woman's greatness filled." Smith also implicitly declared her intention to follow Fuller's example by answering the rhetorical question, "Who shall dare thy harp to take?" Smith (1971: 460-461) responded, "from thy great heart we will take / New courage for the strife / From petty ills our bondage break / And labor with new life".

While Fuller admired the famous talkers of Greece and Rome, translated Goethe's Conversations with Eckermann (1833), and read the literary conversations of Walter Savage Landor, her immediate model for the conversation as a means to self-knowledge and intellectual advancement was the work of Amos Bronson Alcott at his Temple School in Boston. Fuller briefly took Elizabeth Peabody's position as Alcott's assistant at the school in 1836, where, as Capper notes, she became aware of "the concept of conversation as a revolutionary educational tool and a protean cultural force" (Capper 1987: 515). At his Temple School, Alcott affirmed the importance of oral discourse. He said that:

\begin{abstract}
the living man in the presence of the living man, uttering the very thoughts and feelings of his inmost heart, bodying forth in his acts and words the ideal within him, being in himself the truth that he announces - this is the form of address that can worthily give power and efficacy to truth. Speak truth rather than write it - or, if written, give it the life of the spoken, living word (Alcott 1938: 63).
\end{abstract}

During what critics call her "Transcendental Years", 1836-1844, Fuller affirmed her devotion to the spoken word as a means of self-culture and as an important site for significant social change. Early in this period, Amos Bronson Alcott spent an evening in private conversation with Fuller and the Rev. Timothy Dwight. In his journal entry about this March evening, Alcott praised Fuller's genius and her speech:

Miss Fuller seems more inclined to take large and generous views of subjects than any woman of my acquaintance. I think her more liberal than almost any mind among us. She has more of that unspoiled integrity of being, so essential to the apprehension of truth in its unity, than any person of her sex whom I meet; and vastly more of intellectual power. Her skill in conversation is ready; few converse

on conversation appeared in Tait's Magazine; it was later enlarged and reprinted in 1860 in the posthumous volume of DeQuincey's writings. This work is, among other things, a defense of the value of conversation, see Thomas DeQuincey (1890). 
with greater freedom and elegance. Her range of topics seems wide; and she looks at them without narrowness or partiality. Leisure and encouragement will do much for her growth (Alcott 1981: 93).

Six years later, Emerson said much the same thing about Fuller's "pure and purifying mind" and her orality in his journal. Praising her method, judgment, energy, and wisdom, Emerson described Fuller as the most important conversationalist in America and saw her speech infused with "a silver eloquence, which Polymnia taught" (Emerson 1960-1982, 8: 369).

Another contemporary endeavor for adult self-culture through conversation was known to Fuller, who was herself convinced that "women needed a public forum and some practice in thinking together" (Fuller 1983, 1: 38). In the late 1820 s, Elizabeth Peabody held historical conferences for women; these conferences occurred twice weekly for six months. The participants were assigned to read and report on specific materials; then they discussed their reading. Unlike Peabody, however, Fuller did not intend to teach her participants new material. Instead, she proposed:

\footnotetext{
Thus to pass in review the departments of thought and knowledge and endeavor to place them in due relation to one another in our minds. To systematize thought and give a precision in which our sex are so deficient, chiefly, I think because they have so few inducements to test and classify what they receive. To ascertain what pursuits are best suited to us in our time and state of society, and how we may make best use of our means for building up the life of thought upon the life of action (Fuller 1983, 2: 87).
}

In this proposal, Fuller planned to remedy the superficial nature of women's education in a public forum which allowed all speakers "to bear their part, to question, to define, to state and examine in their opinions" (Fuller 1983, 2: 88). Clearly, Fuller drew on her rhetorical training as a model for the proposed forum; she wished to help women test and classify their knowledge agonistically and to "disrupt certain ideological assumptions", in the words of Christina Zwarg, who states that Fuller's success lies in her conversational skills that "negotiate a new understanding of the relationship between public and private worlds" (Zwarg 1995: 211, 254). Insisting that she "would feel coarse and misplaced if I were to be haranguing too much", Fuller wished to make the experience "easy and pleasant" as well as intellectually enriching (Fuller 1983, 2: 88). Thus, an attractive relation between individuals will mark the interactive exchange of thoughts and feelings in Fuller's conversations. Under her supervision, a group of friends will help one another "answer the great questions. What were we born to do? How shall we do it?" (Fuller 1983, 2: 87).

By contemporary testimony, Fuller's conversations were so successful that they continued for five years. On November 6, 1839, Fuller gathered with a 
circle of twenty-five women to begin her experiment in women's conversations. From Elizabeth Peabody's brief account, we know that Fuller explained her goals and her choice of Greek mythology as subject. Part of the first meeting was devoted to dialogue as Fuller found herself "rebutting the cavils of some of the speakers, - who could not bear, in Christian terms, by Christian ladies, that heathen Greeks should be envied" (Emerson 1884, 1: 330). Peabody closed by saying that:

\begin{abstract}
Miss Fuller's thoughts were much illustrated, and all was said with the most captivating address and grace, and with beautiful modesty. The position in which she placed herself with respect to the rest, was entirely lady-like, and companionable. She told what she intended, the earnest purpose with which she came, and with great tact, indicated the indiscretions that might spoil the meeting (Emerson 1884, 1: 331$)$.
\end{abstract}

In a lecture given at the Congress of American Advancement of Women in November 1895, Ednah Dow Cheney discussed attending Fuller's conversations. Remembering forty years before, she said that:

\begin{abstract}
I had the inestimable privilege of attending her conversations for three successive seasons, and I count it among the greatest felicities of my life and I thus came under her influence at a very early age, an influence which has never failed me in all the years of my life ... Whatever she spoke of revealed a hidden meaning, and everything seemed to be put into true relation (Cheney 1902: 205).
\end{abstract}

As well as the young Ednah, the conversations attracted a large circle of educated and liberal thinking women, including Anna Barker, Almira Barlow, Elizabeth Davis Bancroft, Mary Channing, Lydia Maria Child, Sarah Clarke, Lidian Emerson, Eliza Farrar, Mary Ann Haliburton, Elizabeth Hoar, Louisa Gilman Loring, Marianne Jackson, Lidia Cabot Parker, Ann Terry Phillips, Mary, Sophia, and Elizabeth Peabody, Sarah Alden Ripley, Sophia Ripley, Caroline and Ellen Sturgis, Jane Tuckerman, and Maria White. One series held in spring 1841 allowed men to participate; this series was attended by Amos Bronson Alcott, James Freeman Clarke, Ralph Waldo Emerson, Frederick Henry Hedge, George Ripley, Francis G. Shaw, William W. Story, Jones Very, Charles S. Wheeler, and William White.

Fuller covered a broad range of topics that became increasingly focused on social issues. Greek mythology provided the topics for the first series, which ran for thirteen weekly sessions at Elizabeth Peabody's rooms in West Street; the second series in the spring of 1840 was organized around "The Fine Arts". In the fall of 1840, Fuller repeated "The Fine Arts"; and in the spring of 1841, her class of men and women discussed Greek mythology again. The fifth series in November 1841 was concerned with "Ethics"; the spring series the following year focused on 
"Woman" as influenced by family, school, church, society, and literature. The series on "Woman" was a source of inspiration for Fuller's 1844 essay "The Great Lawsuit" and Woman in the nineteenth century (1845). In November 1842, the women discussed a variety of topics like "Persons who never awake to life in this world," "Mistakes," "Faith," "Creeds," "Woman," "Demonology," "Influence," "Catholicism Roman," and "The Ideal". In the winter of 1843-44, Fuller led her dwindling group through consideration of the general topic of "Education," where they discussed "Culture," "Ignorance," "Vanity," "Prudence," "Patience," and "Health". At the end of the five years of classes, Fuller wrote nostalgically about her participants to William $\mathrm{H}$. Channing: "On bidding me goodbye, they all and always show so much goodwill and love, that I feel I must really have become a friend to them" (Fuller 1983, 3: 192).

Unlike Amos Bronson Alcott, Fuller did not direct the literary documentation of her oral discourse. Therefore, the published records of her conversations are few. Two of the fullest records were compiled posthumously, although they rely on contemporary testimony. The first record was published in Fuller's Memoirs (1852) in a chapter called "Conversations in Boston," compiled by Emerson from various sources, including Elizabeth Peabody's notes and Fuller's letters. The second record was published in 1895 by Caroline Healey Dall as Margaret and her friends and is based on Dall's reminiscences and transcriptions of Fuller's conversations on Greek mythology. While both of these records are fragmentary, they reveal the methods and effects of Fuller's oral discourse.

The range of topics covered in Fuller's conversations is quite staggering. As was her custom, Fuller opened the first conversation with a general statement of the subject: "a beautiful sketch of the origin of mythology", which Dall summarized "with scanty justice that my pen can render to Margaret's eloquent talk" (Cheney 1902: 25, 29). Fuller chose Greek mythology as the subject of her first series, as it would be for the first two years, for many reasons, one of which is that Greek mythologies should not be regarded, as they usually were, as superstitious fables, but as narrative metaphors "symbolized of a deep ... intellectual and aesthetic life" (Emerson 1884, 1: 329-330). She considered gods, as she put it, as "great instincts, or ideas, or facts of the internal constitutions, separated, and personified" (Emerson 1884, 1: 330). Prometheus was made the type of Pure Reason, Jupiter of Creative Energy or Will, Minerva, Intellectual Power or Practical Reason, and so on. Fuller's approach, by all accounts, gave women the chance to shed their cultural prejudices and, as she said in one conversation, to "denationalize" themselves. She also encouraged them to see themselves out of the box, in extraordinary terms.

Fuller's intellectually inspired and inspiring conversations, though, were probably not the ones on mythology, but those of her second series on the Fine 
Arts. Emerson's documents for this series were limited to a single letter by an enthusiastic visitor to one of the meetings. However, the series on the Fine Arts was resumed in November 1840, and several significant records remained from this series and another conversation from the spring of 1841. First, Emerson quoted a letter written by Fuller to William H. Channing about the opening of the class; second, he included three records by Peabody: a summary of the whole series, remarks on the fifth conversation, and a transcript of the dialogue that is dated March 1841. Peabody's summary of the second series emphasized Fuller's theory about the Fine Arts which were "one compensation for the necessary prose of life" (Emerson 1884, 1:342). Peabody reported Fuller as saying:

\footnotetext{
The man who could not write his thought of beauty in his life, - the materials of whose life would not work up into poetry, - wrote it in stone, drew it on canvas, breathed it in music, or built it in lofty rhyme. In this statement, however, she guarded her meaning, and said that to seek beauty was to miss it often. We should only seek to live as harmoniously with the great laws as our social and other duties permitted, and solace ourselves with poetry and the fine arts (Emerson 1884, 1: 342$)$.
}

This second series on the Fine Arts took place after Fuller had an ecstatic spiritual experience; Emerson described it by saying that "in the summer and autumn of 1840, she had retreated to some interior shrine, and believed that she came into life and society with some advantage from this devotion" (Emerson 1884, 1: 338). In her letter to Channing, Fuller herself described her enraptured audience and claimed that she had entered into a true relation with the women in her classes: one that resembled the communion of speakers that Alcott sought after in his conversations. As Fuller believed that all dialogue should be mutually inspired and sympathetic, she came to commune with her conversants and to modulate the agonistic potential of the Conversations into a communion of ideas.

Fuller's Conversations demonstrate her belief in the social and intellectual power of conversation. Fuller tried hard, as she had promised in her circular letter to Sophia Ripley, to make her conversations an arena of real intellectual interactions and a well-mannered agnostic experience of self-discovery. She had previously asserted in 1832 that an interactive setting to articulate her ideas was important: "Conversation is my natural element. I need to be called out, and never think alone, without imagining some companion" (Emerson 1884, 1: 137). At times, she asked her women "assistants", as she called them, for written statements of their thoughts, which she would read out loud anonymously and evaluate. She sometimes asked for written definitions of concepts like "faith" or "beauty," about which, she told the women, "We know words, and have vague impressions", but no real ideas (Emerson 1884, 1: 329). She could 
also be at times, according to many accounts, a sharp questioner who enticed women to be critics rather than consumers. In trying to "make those ladies talk", as she put it in a letter to Emerson, she had to confront "that sort of vanity ... which wears the garb of modesty", or, in other words, the nineteenth-century mask of feminine sentimentality, which is the source of women's oppression, making them vulnerable to male domination and control (Fuller 1983, 2: 97). By making interactive communication not only a possibility but a responsibility, Fuller wanted women to shed their masks and to dis-spell the language of phallocracy.

During her period of orality, Fuller was publishing regularly in the Dial, which she edited as well. However, Fuller was concerned that her orality and literacy were somehow incompatible. She wrote to William H. Channing in 1840: "When I meet people I can adapt myself to them, but when I write, it is into another world, not a better one perhaps, but one with very dissimilar habits of thought to this where I am domesticated" (Fuller 1983, 2: 125). To Emerson in the same year, she confessed similar doubts about her ability to find a literary style and form as expressive as her conversation had been for a private circle:

When I look at my papers I feel as if I had never had a thought that was worthy of any but myself, and some fond friends; and it's only, when, on talking with people, I find I tell what they did not know, that my confidence at all returns (Fuller 1983, 2: 127).

Seeking for a viable way to reconcile her orality with her literary ambitions, Fuller wrote her first book in the fall of 1843. Summer on the Lakes, in 1843 was published in 1844 and marks the end of Fuller's career of private eloquence. Fuller considered Summer her effort to capture the attention of a larger audience with her own literary voice. In a letter to Emerson about the printing of the volume, she attested: "all looks auspicious, except that I feel a little cold at the idea of walking forth alone to meet the staring sneering Pit Critic, the Public at large, when I have always been accustomed to confront it from amid a group of 'liberally educated and responsible gentlemen"' (Fuller 1983, 3: 196); and she should have added, liberally educated and respectable gentlewomen.

The primary media of Fuller's influence on women's speaking were her Conversations and the book which evolved from the last series of Conversations, Woman in the nineteenth century (1845), which was, as Emerson reported, praised by Thoreau, who will never like anything, as a "noble piece, rich extempore writing, talking with pen in hand" (Fuller 1983, 3: 183); Emerson himself called it "a piece of life, so much better than a piece of grammar" (Fuller 1983, 3: 183). In her book, Fuller argued repeatedly and forcefully for acceptance of women as public speakers. She refuted contemporary arguments that in public speaking a woman destroyed the beauty of home, or violated the delicacy of her 
sex, noting that the same arguments had been used in opposition to women writing. What women needed, Fuller wrote, was a "chance to use what they have learned, and to learn more, if they can once get a platform on which to stand" (Fuller 1971: 34). Her own experience taught her that "how to get this platform, or how to make it a reasonably easy access, is the difficulty" (Fuller 1971: 49). She cited pioneering women public speakers and performers as exemplars and characterized speaker Abbey Kelly as "a gentle hero" who confronted a mob with "mild decision and womanly calmness" (Fuller 1971: 111).

Truly, what fuller lacked as a speaker were the various audiences and financial opportunities available through an institutional setting such as a lyceum or university; she was intellectually qualified, by her own study, to be a professor - yet there were no women's colleges. She was prepared to be a lecturer - yet there were no organizations which admitted women lecturers. The Boston Conversations for women, a mainstay of her income, needed a larger audience. Unlike men, who could deliver one lecture profitably across the country, Fuller had to prepare anew for each session and for the same local audience - an intellectually exhausting process. In addition, Fuller's audience - and income - was limited by the size of the home in which she presented her discourse as compared to lecture halls and churches in which her male contemporaries appeared.

Unpopular with the cultural mainstream, Fuller's arguments and example nevertheless encouraged the few women who sought empowerment through public discourse. Women who followed Fuller in becoming social and literary critics as lecturers and writers include Julia Ward Howe, Caroline Healey Dall, Edna Dow Cheney, Mary A. Livermore, and Elizabeth Oakes Smith. ${ }^{4}$ The influence of Fuller's ideas can be traced along several lines: in art criticism (Cheney), literary and social criticism (Howe, Cheney, Dall), woman's vocational opportunities (Dall), Women's health (Livermore, Cheney), and women's rights (all five women). Not only did these women carry on Fuller's work, they also wrote and lectured about her, sustaining her ideas and preserving her biography as a symbol of heroic living and intellectual achievement. Like Fuller, they found creative ways of positioning women's discourse in male / public domains, each making her own very separate and individual contribution to the ongoing discussions of the day. They also exceeded Fuller's example in becoming lecturers to mixed-sex audiences of strangers.

Fuller and her successors who joined the ranks of professional public speakers played a historic role in the development of women's public discourse and

$4 \quad$ Fuller's public speaking in her Conversations stimulated a tradition of literary and social criticism in writing and lecturing. For a study of five women writer-speakers who were inspired by Fuller's work and who contributed to the Fuller legacy by writing and lecturing about her, see Bean (1998). 
merit a place in a distinctive women's oratorical history. Through discourse and example, Fuller founded a tradition of women's public speaking that expressed concern for the vital issues of the day from a humanitarian vision and relied on a powerful voice speaking to society. In her Boston Conversations, Fuller, who was implicitly labeled a siren, initiated dialogues and thrived on the interchange of ideas, the intermeshing or interlacing of minds engaged with vital questions of the day. She overcame or destabilized the boundaries of male and female discourse, of public and private spheres. The attraction of her Conversations was not in her appearance nor in her voice; reports typically commented that her voice was initially grating to the listener's ear. In the press she was credited with "a wonderful command of language, ready wit, speaking fancy, and a contagious enthusiasm", and with a "magnetic power which thrilled and charmed and made her presence an inspiration" (Boutell 1980: 701).

By all accounts, Fuller's importance to her culture cannot be fully understood without accounting for her intellectual powerful voices. Through her eloquent private and public speaking voices, Fuller exemplified a woman's possibility for independence and a contemplative life. In her Conversations held for well-educated and thinking women, Fuller fashioned a complex self, stimulated women to develop their minds, and helped transform the collective voice of American womanhood during the mid-nineteenth century. She created a vibrant legacy for her culture through speaking, and her speaking engraved a lasting impression on the American imagination. It has even been said that "her quick mind seems to have been an electric current that stimulated other minds to activity" (Parrington 1980: 143). In her final years, Fuller envisioned a future that would revolutionize women's position in a progression toward universal human rights which would liberate women, slaves, and the working class. Her prophetic voice sounded in warnings, challenges, and visionary proclamations powerful acts of self-assertion for a woman in her time.

Margaret Fuller was described both as a heroic figure and as a representative woman. Caroline Dall (1972: 112, 371) placed a heroic Fuller with Charlotte Bronte on "thrones of feminine power in the Old and New worlds", an oracle and a prophetess; Julia Ward Howe (1970: vi) ranked Fuller with Elizabeth Barrett Browning and George Sand as social prophets or sibyls of the nineteenth century. On the other hand, Mary Livermore (1968: 414) solved the problem of representing an exceptional woman by arguing that Fuller was a representative woman who did not "surpass her sex" but fulfilled the full potential of womanhood. Fuller, as a bearer of the living word and as a champion of public discourse, encapsulated the forceful nature of women speaking in public and experiencing thought as passing into action. She was possessed of a well-balanced mind, a self-reliant soul, and the power of acting as a touchstone to all who listened, stimulating American women to blaze an upward path, or as Fuller 
described it in Woman, to obtain "mastery over outward" or worldly existence, through an "initiation into inward life" or "spirituality", and "severe discipline of faculty" or purity (Fuller 1971: 114). Able to exemplify the self-culture that she advocated in her Conversations, Fuller came to assert her independent agency by becoming a speaking subject. In her, we see what a woman achieved for herself through the dynamics of conversation, of voice. Not so much fame or honor, these are of minor importance, but a whole self, a cultivated intellect, right judgment, self-knowledge, and self-happiness.

\section{REFERENCES}

\section{PRIMARY SOURCES}

Alcott, Amos B.

1938 The journals of Bronson Alcott. (Edited by Odell Shepard.) Boston: Little.

1969 The letters of A. Bronson Alcott. (Edited by Richard L. Herrnstadt.) Ames: Iowa State University Press.

1981 “'Journal for 1837' (Part One)", Studies in the American Renaissance: 27-132. Emerson, Ralph W.

1903-1904 The complete works of Ralph Waldo Emerson. 12 vols. (Edited by Edward Emerson.) Boston: Houghton.

1939 The letters of Ralph Waldo Emerson. 6 vols. (Edited by Ralph L. Rusk.) New York: Columbia University Press.

1960-1982 The journals and miscellaneous notebooks. 16 vols. (Edited by William Gilman et al.) Cambridge: Harvard University Press.

Fuller, Margaret

1843 "The great lawsuit: Man vs. Men; Woman vs. Women", The Dial 4: 1-47.

1855 Woman in the nineteenth century. (Reprint.) New York: Norton.

1983 The letters of Margaret Fuller. 5 vols to date. (Edited by Robert N. Hudspeth.) Ithaca: Cornell University Press.

\section{SECONDARY SOURCES}

Bean Mattson, Judith

1998 "'A presence among us': Fuller's place in nineteenth century oral culture", ESQ 44: $79-112$.

Blanchard, Paula

1987 Margaret Fuller: From Transcendentalism to Revolution. Reading, Mass.: AddisonWesley.

Boutell, L. H.

1980 “Margaret Fuller Ossoli”, The Chatuaguan 11: 701.

Brigance, William (ed.)

1943 A history and criticism of American public address. New York: Russell and Russell. 
Capper, Charles

1987 "Margaret Fuller as cultural reformer: The Conversations in Boston", American Quarterly 39: 509-528.

Capper, Charles

1992 Margaret Fuller. An American Romantic life, the private years. Vol 1. New York: Oxford University Press.

Cheney Dow, Ednah

1902 Reminiscences of Ednah Dow Cheney. Boston: Lee and Shepard.

[1889]

1980 Louisa May Alcott: Her life, letters and journals. New York: Chelsea House.

Chevigny, Bell G.

1976 The woman and the myth: Margaret Fuller's life and writings. New York: The Feminist Press.

Cole, Phyllis

1998 "The nineteenth-century women's rights movements and the canonization of Margaret Fuller", ESQ 44: 1-33.

Dall, Caroline H.

1867 The college, the market, and the court; or, woman's relation to education, labor, and law. Boston: Lee and Shepard.

1972 Margaret Fuller and her friends, or ten conversations with Margaret Fuller upon the mythology of the Greeks and its expression in art. New York: Arno Press, 1972.

DeQuincey, Thomas

1890 The collected writings of Thomas DeQuincey. 14 vols. (Edited by David Masson.) Edinburgh: Adam and Charles Black, 10: 264-288.

Ellison, Julie

1990 Delicate subjects: Romanticism, gender, and the ethics of understanding. Ithaca: Cornell University Press.

Fleischman, Fritz (ed.)

2000 Margaret Fuller's cultural critique: Her age and legacy. New York: Peter Lang.

Fuller, Arthur B. (ed.)

[1869]

1968 Woman in the nineteenth century and kindred papers. New York: Greenwood Press.

Fuller, Arthur B. (ed.)

[1856]

1971 At home and abroad, or things and thoughts in America and Europe by Margaret Fuller. (Reprint.) Port Washington, New York: Kennikat Press.

Howe Ward, Julia

1903 "Introduction", in: Love-letters of Margaret Fuller. New York: AMS Press, v-xvi.

Livermore, Mary A.

[1869]

1968 "Margaret Fuller Ossoli, a represtentative woman", in: Arthur B. Fuller (ed.), 148157.

Myerson, Joel (ed.)

1994 Studies in the American Renaissance. Charlottesville: University Press of Virginia. Myerson, Joel (ed.)

1980 Critical essays on Margaret Fuller. Boston: G. K. Hall. 
O’Connor, Lilian

1954 Pioneer women orators. New York: Columbia University Press.

Parrington, Vernon L.

1980 "Margaret Fuller, rebel”, in: Joel Myerson (ed.), 143-149.

Robinson, David M.

1982 "Margaret Fuller and the Transcendental ethos: Woman in the nineteenth century", PMLA 97: 83-98.

Simmons Craig, Nancy

1994 "Margaret Fuller's Boston Conversations: The 1839-1840 Series", in: Joel Myerson (ed.), 195-226.

Smith Oakes, Elizabeth

[1856]

1971 "To the memory of Margaret Fuller", in: Arthur B. Fuller (ed.), 1.

Watson, David

1988 Margaret Fuller: An American Romantic. (Berg Women's Series.) Oxford: Berg.

Yoakum, Doris

1943 "Women's introduction to the American Platform", in: William Brigance (ed.), 15392.

Zwarg, Christina

1995 Feminist conversations: Fuller, Emerson, and the play of reading. Ithaca: Cornell University Press. 